\title{
Strength is length
}

\author{
Xiaoliang Luo \\ Université d'Orléans \\ xiaoliang.luo@univ-orleans.fr \\ Guillaume Enguehard \\ Université d'Orléans \\ guillaume.enguehard@univ-orleans.fr
}

\begin{abstract}
In this paper, we propose that the contexts of fortition and lenition can be represented with a very simple autosegmental tool: branching. We point out a major shortcoming of Coda Mirror Theory: though this model tries to account for strength with lateral relations, length should also be factored in order to account for the inalterability of geminates. In order to unify the principles that regulate strength, we propose a consistent theory built exclusively on length, without lateral relations.
\end{abstract}

Keywords: lenition; fortition; strength; length; Strict CV

\section{Introduction}

The analysis in this paper is part of a larger project to develop a strict CV framework (Lowenstamm 1996; Scheer 2004) without the lateral relations inherited from Government Phonology (Kaye et al. 1990). The role of lateral relations in vowel/zero alternations and the structure of branching onsets was already questioned in Enguehard (2018a; b; 2019) and Enguehard \& Luo (2019). In this paper, we specifically focus on the role of Government and Licensing in the representation of fortition and lenition proposed in Strict CV (Ségéral \& Scheer 1999; 2001b). We argue that strength does not result from lateral relations. It results from phonological branching, which is itself regulated by the Line Crossing Constraint.

In section 2, we introduce the basics of Coda Mirror Theory, proposed in Ségéral \& Scheer $(1999 ; 2001 b)$ to account for the distribution of fortition and lenition. In section 3, we point out that this theory fails to account for the specific inalterability of geminates. For this, it is necessary to refer to length. In section 4, we suggest that length is the only factor that conditions strength. Based on the notion of "virtual length", we propose that stronger segments are systematically longer while weaker segments are systematically shorter. 


\section{Theoretical background}

In this section, we recall how strength can be captured by lateral relations. Firstly, we illustrate the distinction between strong and weak syllabic positions. Secondly, we introduce the basics of Coda Mirror Theory.

\subsection{Lenition and fortition}

It is a well-known fact that consonants can have different realizations depending on their syllabic position. This is illustrated in (1) by the evolution of Proto-Germanic /p/ in High German (Ségéral \& Scheer 2008, 142). The original voiceless labial plosive corresponding to English $\langle p\rangle$ became: i. affricated in initial and post-coda positions $(1 \mathrm{a}, \mathrm{b})$; and ii. spirantized in intervocalic and coda positions $(1 \mathrm{c}, \mathrm{d})$. This diachronic phenomenon echoes a synchronic situation: at one stage of the history of the German language, the realization of $/ \mathrm{p} /$ depended on syllabic positions.

\begin{tabular}{|c|c|c|c|}
\hline a. $\quad \#-$ & $\begin{array}{l}\text { English } \\
\langle\text { path }\rangle\end{array}$ & $\begin{array}{l}\text { High German } \\
\langle\mathbf{P f a d}\rangle\end{array}$ & $\begin{array}{l}\text { Gloss } \\
\text { 'door' }\end{array}$ \\
\hline b. C. & $\langle\operatorname{carp}\rangle$ & $\langle$ Karpfen $\rangle$ & 'mole' \\
\hline c. $\mathrm{V} \_\mathrm{V}$ & $\langle$ pope $\rangle$ & $\langle$ Pfaffe $\rangle$ & 'shore' \\
\hline d. $\quad$. C & $\langle$ scheep $\rangle$ & $\langle$ Schaf $\rangle$ & 'road' \\
\hline
\end{tabular}

This phenomenon illustrates two relevant contexts for the realization of consonants. These contexts are generally referred to as strong and weak for the following reason. It is assumed (Thurneysen 1946, 74; Martinet 1955, §6.5-6.8, §6.49; Harris 1990, 257, Lavoie 2001, 5-8, among others) that less sonorous consonants are stronger and more sonorous consonants are weaker. Thus, contexts where less sonorous realizations of consonants are found are considered as strong, and contexts where more sonorous realizations of consonants are found are considered as weak. Such a definition is based on substantial cues, i.e., phonetic salience or change trajectories, which disagree on some aspects (see Honeybone 2001 for discussion). In our paper, we follow a more formal approach. We consider as lenition those processes that lead to the loss of phonemic contrast (framed in our data). In this respect, spirantization in (1) is a weakening effect because it neutralizes the contrast between plosives and fricatives. As for affrication, it is a strengthening effect because it does not neutralize any contrast.

Parametrically, the weak context can be divided into two sub-types. For instance, see the evolution of Latin /p/ in French (Ségéral \& Scheer $2008,137)$ represented in $(2)$. The voiceless labial plosive evolved in the 
following way: i. it remained unchanged in initial and post-coda positions $(2 \mathrm{a}, \mathrm{b})$; ii. it was spirantized in intervocalic positions $(2 \mathrm{c})$; and iii. it was dropped in coda position $(2 \mathrm{~d})$. Two weak contexts (framed) need to be distinguished: $(2 \mathrm{c})$ and $(2 \mathrm{~d})$.

(2)

\begin{tabular}{|c|c|c|c|}
\hline a. $\#$ & $\begin{array}{l}\text { Latin } \\
\langle\text { porta }\rangle\end{array}$ & $\begin{array}{l}\text { French } \\
\langle\text { porte }\rangle\end{array}$ & $\begin{array}{l}\text { Gloss } \\
\text { 'door' }\end{array}$ \\
\hline b. C. & $\langle$ talpa $\rangle$ & $\langle$ taupe $\rangle$ & 'mole' \\
\hline c. $\quad \mathrm{V}-\mathrm{V}$ & $\langle$ ripa $\rangle$ & $\langle$ rive $\rangle$ & 'shore' \\
\hline d. $\quad$. C & $\langle$ rupta $\rangle$ & $\langle$ route $\rangle$ & 'road' \\
\hline
\end{tabular}

A similar distribution of strong and weak contexts can be observed in several other languages, e.g., Greek, Polish, Korean (among others) (see Ségéral \& Scheer 2008). In order to account for this wide-spread crosslinguistic phenomenon, Ségéral and Scheer $(1999 ; 2001 b)$ have undertaken to propose a universal model of strength based on two lateral relations: Government and Licensing.

\subsection{Government and Licensing}

Government and Licensing were popularized by Kaye et al. (1990) and Charette (1990), respectively. They represent two types of relations connecting syllabic constituents. The distribution of Government and Licensing changed considerably through the history of Government Phonology. We will not address the details of this evolution. In short, Government and Licensing were first conceived as prosodic dependency relations, then multiplied in order to account for various syllabic phenomena (branching onsets, codas, etc.). Among these relations, we can cite: Proper Government (Kaye et al. 1990), Interonset Government (Gussmann \& Kaye 1993), Infrasegmental Government (Scheer 1996), Government Licensing (Charette 1990; 1991), Coda Licensing (Kaye 1990), Magic Licensing (Kaye 1992), M-command and A-command (Pöchtrager 2006). Some models maintained some of these distinctions (see Cyran 2010), while others tried to reduce them. In their introduction to Coda Mirror theory, Ségéral and Scheer (1999, 17-21) proposed to unify them into two basic notions: Government and Licensing. As a baseline, we here follow the recent developments proposed in Scheer \& Ziková (2010). These authors assume that Government and Licensing have the following distributional properties: i. they originate from an active $\mathrm{V}$-position; ii. they locally target a preceding $\mathrm{V}$ - or 
C-position; and iii. they cannot target the same constituent. ${ }^{1}$ An illustration of two possible lateral configurations is given in $(3 \mathrm{a}, \mathrm{b})$.

(3) a.

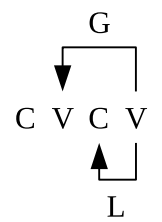

b.

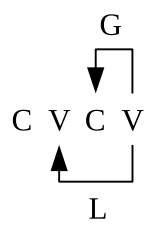

As mentioned above, in Kaye's et al. (1990) landmark paper in Government Phonology, lateral relations were not aimed at accounting for positional strength: they were intended to derive syllabic structure. Proper Government originally allowed a nuclear position to be uninterpreted (4a) (see the Empty Category Principle of $i b i d ., 219)$, while Licensing allowed a rhymal position to be interpreted (4b) (Kaye 1990, 311). It is worth observing that these effects on the interpretation of syllabic constituents are opposed (see Ségéral \& Scheer 1999, 19). The first is an inhibitory effect because it allows something to be uninterpreted. The second is an strengthening effect because it allows something to be interpreted.

(4) a. A position may be uninterpreted phonetically if it is properly governed.

b. Post-nuclear rhymal positions must be licensed by a following onset.

In privative representational systems, segments are made up of a limited number of basic features and their combination. Following Harris (1990, 274), Cyran $(1997 ; 2010)$ and Pöchtrager $(2006,55)$, the strength of segments is proportional to the amount of entities in their internal structure. This notion is called "complexity". The idea that Government has an inhibitory effect on the complexity of vowels and consonants was first proposed by Harris $(1990,274)(5)$. In this paper, Harris argues that codas are inhibited because they are governed by a following onset. ${ }^{2}$

(5) Let $\alpha$ and $\beta$ be segments occupying the positions $A$ and $B$ respectively. Then, if $A$ governs $B, \beta$ must be no more complex than $\alpha$.

${ }^{1}$ Active V-positions are non-empty or final.

${ }^{2}$ In the first version of Government Phonology, lateral relations could originate from an onset. This type of Government is called "Interonset Government" in Gussmann \& Kaye (1993). 
Ségéral and Scheer (2001b) follow this proposal and extend it to Licensing. They assume that Licensing has a strengthening effect mirroring the inhibitory effect of Government. Thus, if the realization of a consonant can be inhibited by Government, then it can be empowered by Licensing. Following the distribution of lateral relations proposed in Scheer \& Ziková (2010), three possibilities can be derived, as shown in (6). ${ }^{3}$ In (6a), the non-intervocalic onset is in a strong position because it is licensed, while in $(6 \mathrm{~b}, \mathrm{c})$, intervocalic onsets and codas are in weak positions because they are not licensed. The two distinct weak contexts of French $(2 \mathrm{c}, \mathrm{d})$ can be derived from the (in)activity of the nucleus on the right of the consonant. Provided that empty nuclei are unable to govern (Kaye et al. 1990), the consonants in (6b) and (6c) are not in the same configuration. In the first case (6b), the consonant is governed. In the second case (6c), it is ungoverned. Thus, we expect them to show different degrees of strength. ${ }^{4}$

(6) a. non-intervocalic onset

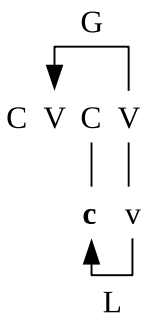

b. intervocalic onset

c. coda

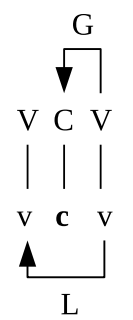

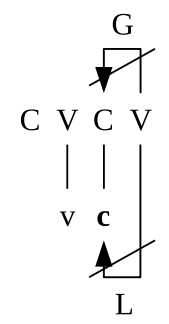

Associated with the proposition of Lowenstamm (1999), this definition of strong and weak contexts based on lateral relations makes a strong prediction. According to Lowenstamm (1999), the beginning of the word is phonologically manifested by an empty CV (7a). Following the principle in (4a), the V-position of this empty CV must be governed. In the same way, the empty $\mathrm{V}$-position that precedes a post-coda onset $(7 \mathrm{~b})$ cannot remain empty without being governed. As a consequence, both initial and post-coda onsets are licensed and ungoverned. Thus, the theory unifies the two non-intervocalic onset positions in $(1 \mathrm{a}, \mathrm{b})$ and $(2 \mathrm{a}, \mathrm{b})$ with respect to strength. These are renamed "Coda Mirror" positions.

3 The distribution of lateral relations is slightly different in Ségéral \& Scheer (1999; 2001b). This difference is not relevant to the present paper.

${ }^{4}$ In these representations, intervocalic onsets are supposed to be weaker than codas because they are inhibited by Government. This prediction is not necessarily in line with the data (especially (2)). We return to this point in section 4. 
(7) a.

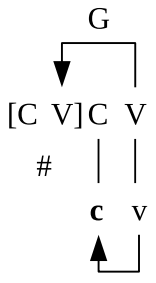

$\mathrm{L}$ b.

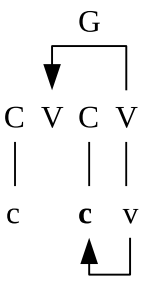

$\mathrm{L}$

In short, the theory of Ségéral \& Scheer (2001b) and Scheer \& Ziková (2010) implies the classification of weak and strong positions outlined in (8).

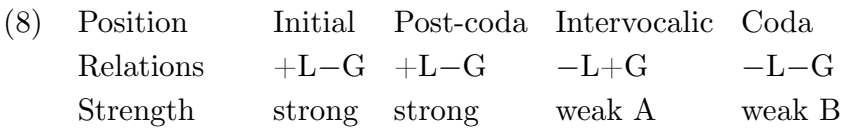

Coda Mirror Theory was credited with deriving the distribution of strength with tools originally serving to derive other syllabic phenomena. But we show in the following section that lateral relations are not the only factor conditioning strength.

\section{The role of length}

In this section, we argue that Government and Licensing are not sufficient to account for the strength of segments. We base our argumentation on the inalterability of long segments.

\subsection{The inalterability of long segments}

The inalterability of long segments is a well-known phenomenon discussed in Kenstowicz (1970); Guerssel (1977; 1978); Leben (1980); Steriade (1982); Steriade \& Schein (1984) and Hayes (1986) (among others). Rules that condition the realization of a segment in a given syllabic position unexpectedly fail to influence long segments in the same position. This phenomenon concerns both consonants and vowels. We discuss two examples below. 
Hayes $(1986,321)$ illustrates the inalterability of geminates with the case of Persian in (9). In this language, we observe a lenition process that changes $/ \mathrm{v} /$ to $/ \mathrm{w} /$ (framed). This process can be observed in coda position (9a), but not in onset position (9b). Now, since geminates belong to the coda of a syllable and to the onset of another syllable, we should expect a lenition of their "coda part" (e.g., *[æwvæl]). But unexpectedly, Persian tautomorphemic geminates do not undergo the lenition observed in coda position (9c).

(9)

\begin{tabular}{|c|c|c|}
\hline & Persian & Gloss \\
\hline a. & $\begin{array}{l}\text { [now-ru:z] } \\
\text { [jow] }\end{array}$ & $\begin{array}{l}\text { 'New Year' } \\
\text { 'barley' }\end{array}$ \\
\hline & [nov-i:n] & 'new kind' \\
\hline & [jæv-i:n] & 'made of barley' \\
\hline$C$ & [ævvæl] & 'first' \\
\hline & [morovvæt] & 'generosity' \\
\hline
\end{tabular}

A similar phenomenon can be observed with vowels in Moroccan Arabic (see Lowenstamm 1991, 959). The short vowels of Classical Arabic are dropped or replaced by centralized vowels (10a). However, long vowels do not undergo the same change: they shorten but maintain their quality (10b). This evolution implies that, at a certain stage in the history of Arabic, the quality of short vowels was neutralized while the quality of long vowels was maintained.

\begin{tabular}{|c|c|c|}
\hline Classical Arabic & Moroccan Arabic & Gloss \\
\hline /himaar/ & [hmmar] & 'donkey' \\
\hline /taktubu/ & [tiktib] & 'you are writing' \\
\hline /muslim/ & [mislim] & 'muslim' \\
\hline /taktubuu/ & [tiktibu] & 'you are writing' \\
\hline /kariim/ & [krim] & 'generous' \\
\hline /mubaarak/ & [mbark] & 'blessed' \\
\hline
\end{tabular}

The inalterability of long vowels is not only highlighted by reduction phenomena. For instance, in Korean, place assimilation can take place between /i/ and a preceding short vowel (11a) but not between /i/ and a preceding long vowel (11b) (Charette 1989, 171-174). 
(11)

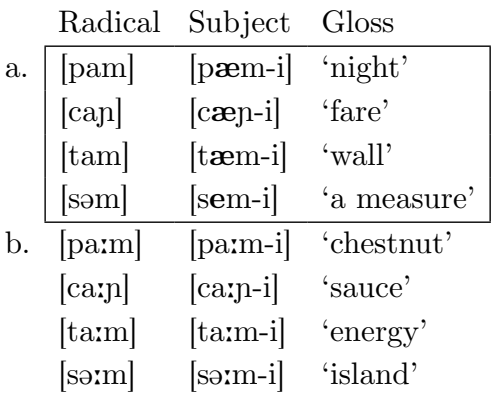

Steriade (1982) and Steriade and Schein $(1984,265)$ argue that autosegmental phonology can predict the inalterability of long segments in cases like (9) and (10). They point out that, following the Obligatory Contour Principle (Leben 1973; McCarthy 1986), geminates are supposed to be a single segment branching on two positions. ${ }^{5}$ Based on this representation, Steriade and Schein $(1984,265)$ proposed the principle in (12). Roughlyspeaking, this principle states that a geminate cannot undergo a change unless this change targets both codas and onsets.

(12) A structure-dependent rule will fail to affect the contents of a segmental matrix unless all skeleton slots associated to it meet the structural description.

This principle accounts for the fact that the "two parts" of the geminate do not undergo distinct realizations, but it does not really capture the fact that long segments are unlikely to be lenited. Indeed, in such a rule-based approach, one could implement a language-specific lenition rule targeting codas and onsets, and thus affecting the two parts of the geminate.

The Coda Mirror Theory resolves this issue by introducing a universal representation of strong positions. Consider the representation of geminates in (13a). These include an empty nucleus which must be governed. As a consequence, the geminate is in a strong position because it is only licensed. ${ }^{6}$ Unfortunately, the same reasoning cannot be applied to the case of long vowels. Though these are supposed to be licensed and un-

${ }^{5}$ However, when a geminate is heteromorphemic, its representation as a branching structure is optional. Because the two components of the geminate can belong to distinct morphological tiers, the Obligatory Contour Principle might not apply (McCarthy 1986). This is the case in Persian where the two parts of heteromorphemic geminates have distinct realizations (e.g., / xosrav-var/ : [xosrow-var] 'kingly', Kambuziya 2003, 14).

${ }^{6}$ There is no alternative representation of geminates in Coda Mirror Theory. Since a geminate cannot occur after a coda (e.g., an obstruent in *ktt), the embedded nucleus is necessarily subject to the Empty Category Principle. If it were not, the geminate 
governed (13b), short vowels undergo identical lateral relations (cf. (6b)). As a consequence, the model predicts that short vowels and long vowels have the same degree of strength.

(13) a.

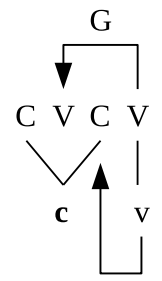

L b.

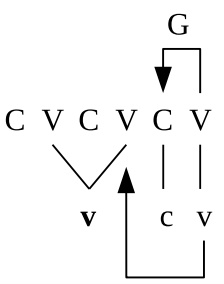

$\mathrm{L}$

In other words, there is no reason for a long vowel to be stronger than a short vowel, except the fact that it is long.

\subsection{The limits of the Coda Mirror}

We now discuss three cases where Coda Mirror Theory fails to account for the inalterability of geminates. Our examples come from three unrelated languages: Tamazight (Afro-Asiatic family), Old Norse (Indo-European family) and Koalib (Niger-Congo family).

We saw that Coda Mirror Theory predicts that geminates are in a strong position (14a) because they undergo the same lateral relations as post-coda onsets (14b): they are licensed and ungoverned. In other terms, we expect that geminates should always have the same realization as postcoda onsets.

(14) a.

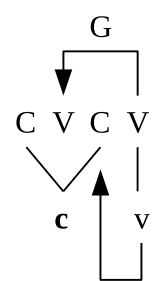

$\mathrm{L}$ b.

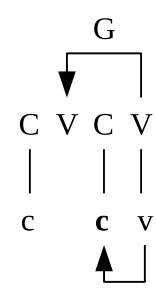

$\mathrm{L}$

would be targetted by government. In this case, the result would be weaker than a post-coda onset, which is only licensed. This is not what we observe. 
However, this is not always the case, as shown by the example of the Tamazight dialect discussed in Saib $(1974,4)(15)$. In this variety, the zero form of the roots in (15a) has an underlying template $\mathrm{eC}_{1} \mathrm{C}_{2} \mathrm{eC}_{3}$ while the intensive form has an underlying template $\mathrm{C}_{1} \mathrm{eC}_{2} \mathrm{C}_{2} \mathrm{eC}_{3}$ (15b). ${ }^{7}$ The second stem consonant is a post-coda onset in the first case and a geminate in the second case. Following the representations in $(14 a, b)$, we expect $\mathrm{C}_{2}$ to have the same realization in both templates. Yet, it is a fricative in (15a) and a plosive in $(15 \mathrm{~b}) .^{8}$

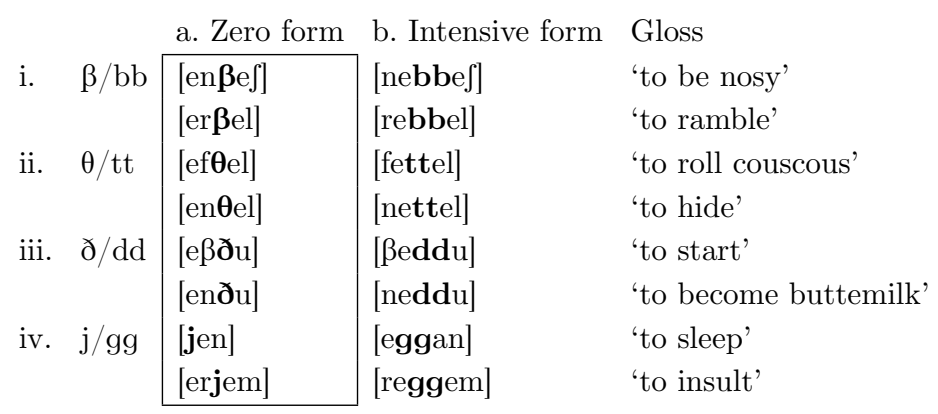

A similar phenomenon can be observed for the formation of the past in Old Norse (source: Zoëga 1910), as illustrated in (16). The past suffix is $-d a(16 \mathrm{a}, \mathrm{c})$ or $-\partial a(16 \mathrm{~b})$. The variant $-d a$ is found when it forms a geminate with the preceding consonant (16a) or when it is preceded by a nasal or lateral consonant (16c), while the variant - $\partial a$ is found after another obstruent or the rhotic $/ \mathrm{r} /(16 \mathrm{~b}) .{ }^{9}$ As in the previous example, geminates do not behave like post-coda onsets: they avoid spirantization. This distinction cannot be captured by the representations in $(14 \mathrm{a}, \mathrm{b})$.

${ }^{7}$ As in most Semitic languages, the homogeneity of the template can be made opaque in the surface form by morpho-phonological conditions (vocalization of glides, biliteral roots, etc.).

${ }^{8}$ Note that the segmental context is not relevant: the weak form of $\mathrm{C}_{2}$ in (15a) can be preceded by a sonorant (e.g., [en $\boldsymbol{\theta e l}]$ ) or an obstruent (e.g., [ef $\boldsymbol{\theta} \mathrm{el}]$ ).

${ }^{9}$ The case in (16c) is shared with several spirantizing dialects of Tamazight (Kossmann $2000,10)$. We set this aside for further studies. Our working hypothesis is that non rhotic sonorants identified by $\langle\mathrm{m}\rangle,\langle\mathrm{n}\rangle,\langle\mathrm{ng}\rangle$ and $\langle\mathrm{l}\rangle$ share an occlusion feature with the following plosive (see Backley 2011, 117, and Ulfsbjorninn \& Lahrouchi 2016, $115)$, thus generating a pseudo-geminate. Note that $\langle\mathrm{g}\rangle$ in (16b) is not a plosive. It is supposed to be realized as a fricative (Gordon \& Taylor 1957, §25). 
(16) Infinitive Past (1SG) Gloss

$\begin{array}{llll}\text { a. } & \langle\text { klæða }\rangle & \langle\text { klæd-da }\rangle & \text { 'to clothe' } \\ & \langle\text { leiða }\rangle & \langle\text { leid-da }\rangle & \text { 'to lead' } \\ & \langle\text { rœða }\rangle & \langle\text { rœd-da }\rangle & \text { 'to speak' } \\ & \langle\text { stríða }\rangle & \langle\text { stríd-da }\rangle & \text { 'to harm' } \\ \text { b. } & \langle\text { deyfa }\rangle & \langle\text { deyf-ða }\rangle & \text { 'to make deaf' } \\ & \langle\text { leiga }\rangle & \langle\text { leig-ða }\rangle & \text { 'to hire' } \\ & \langle\text { fylgja }\rangle & \langle\text { fylg-ða }\rangle & \text { 'to accompany' } \\ & \langle\text { gøra }\rangle & \langle\text { gør-ða }\rangle & \text { 'to make' } \\ \text { c. } & \langle\text { døema }\rangle & \langle\text { døem-da }\rangle & \text { 'to give judgement' } \\ & \langle\text { spyrna }\rangle & \langle\text { spyrn-da }\rangle & \text { 'to spurn' } \\ & \langle\text { lengja }\rangle & \langle\text { leng-da }\rangle & \text { 'to lengthen' } \\ & \langle\text { deila }\rangle & \langle\text { deil-da }\rangle & \text { 'to divide into parts' }\end{array}$

Finally, a difference between geminates and post-coda onsets can also be observed in Koalib (Quint 2006). Table (17) give some examples of underlying plosives in the relevant syllabic positions.

\begin{tabular}{|c|c|c|c|c|c|}
\hline \multirow{4}{*}{ a. } & \multirow{3}{*}{$/ \mathrm{p} /$} & \multirow{3}{*}{$\begin{array}{l}\text { i. \#- } \\
\text { /póorè/ } \\
\text { [fóorè] }\end{array}$} & ii. C. & iii. $\mathrm{V} \_\mathrm{V}$ & iv. _. C \\
\hline & & & /kèpótpòt/ & / '́ерù/ & /lópró/ \\
\hline & & & [kèvóðvòt] & [éevù] & [lóvró] \\
\hline & & 'light' & 'lung' & 'fifth daughter' & 'hole' \\
\hline & $/ \mathrm{t} /$ & /tóoywór/ & /tòptànnà/ & /káaté/ & /lòtywòr/ \\
\hline & & [tóoywór] & [tòvðànnà] & [káaðé] & [l’̀ðywว̀r] \\
\hline & & 'elephant' & 'perfection' & 'termite' & 'snore' \\
\hline & $/ \mathrm{k} /$ & /kómpór/ & / lètgèny/ & /kwâaké/ & /kwêkré/ \\
\hline & & [kómbór] & [lغ̇ðgغ̀n] & [kwâagé] & [kwêgré] \\
\hline & & 'door wing' & 'earlobe' & 'he will take' & 'he will gallop' \\
\hline b. & $/ \mathrm{pp} /$ & /ppûp/ & /yòrppó/ & /kàpòppór/ & $\overline{-}$ \\
\hline & & [pûp] & [yòrpó] & [kàvòppór] & \\
\hline & & 'all at once' & 'tomorrow' & 'butterfly' & \\
\hline & $/ \mathrm{tt} /$ & /ttûp/ & /órttà/ & /kéttóy/ & 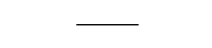 \\
\hline & & [tûp] & [órtà] & [kéttóy] & \\
\hline & & 'fully' & 'soldiers' & 'gecko' & \\
\hline & /kk/ & /kkèlé-kkèlé-kkèlé/ & / kwòrkkòrày/ & /lékké/ & - \\
\hline & & [kèlé-kèlé-kèlé] & [kwòrkòràn] & [lékké] & \\
\hline & & 'tickle' & 'tamarind seed' & 'crippled' & \\
\hline
\end{tabular}

A comparison of (17a) and (17b) reveals that singletons (17a) are lenited in all non-initial positions (framed), while geminates (17b) are never lenited (though they can be simplified). This is more striking when one compares (17a.ii) and (17b.iii). Post-coda onsets are spirantized but geminates are 
not. Once again, this realizational distinction cannot be explained by the lateral relations in (14). Provided that post-coda onsets and geminates undergo the same lateral relations, we expect them to have the same realization (e.g., [tòvðànnà], *[kéððóy] or [tòvtànnà], *[kéttón]).

Two other issues concerning the realization of consonants can be observed in Koalib. First, /p/ is unexpectedly realized as [f] in initial position (17a.i). In the context of this paper, we will set this issue aside. Second, final codas have the same realization as initial onsets (expect /p/): e.g., compare (17a.i) with /kóròp/ : [kóròp] 'sound of a splintering item', /ppât/ : [pât] 'in small pieces', /ć́k-còk/ : [jógzòk] 'adze' (Quint 2006). We return to this issue in section 4 .

To sum up, the three languages we mentioned show that Government and Licensing are not sufficient to account for the strength of consonants. In some cases, another factor is involved. Comparing the representations of geminates and post-coda onsets in (14) (outlined in 18), the only difference between the two is length.

(18) a.

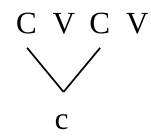

$[+\mathrm{L},-\mathrm{G}]$ b.

$$
\begin{gathered}
\left.\right|_{\text {C V }} \\
\text { C } \\
{[+L,-G]}
\end{gathered}
$$

The idea that a branching structure can be responsible for the strength of a segment was already developed in Hayes (1986), Charette (1989), Honeybone (2005) and Bucci (2013) (among others). That being said, these studies maintain a duality between syllabic and length factors. In this paper, we aim to argue that strength can be reduced to only one of these factors.

\section{Strength is length}

In this section, we argue that length is the only factor responsible for the strength of consonants. For this, we introduce the notion of virtual length and we propose a representation of strength based on phonological branching and the Line Crossing Constraint. 


\subsection{Virtual length}

In the preceding sections, we referred to length as a phonological or phonetic phenomenon indistinctly. However, several studies in recent decades argue that phonological length is not necessarily realized as phonetic length. It can also be realized as quality. Such a claim was defended in Lowenstamm (1991, 959); Carvalho (1994, 23); Ségéral (1995, 150-152); Bendjaballah (1999, 31-33) and Fathi (2013, 25-28) for vowels; as well as in Jensen (1994); Larsen (1994, 90); Banksira (2000); Ségéral \& Scheer (2001a); Barillot (2002, 248-264; 496-499); Barillot \& Ségéral (2005); Bendjaballah (2012, 138-142) and Faust (2018) for consonants.

Consider the example of Somali discussed in Ségéral \& Scheer (2001a, 323). This language has an autobenefactive suffix $-(a) t$ which is followed by the person suffix. When $-(a) t$ is followed by the zero suffix of the first person singular, it is realized as [ð] (19a). But when -(a)t and the second person singular suffix $-t$ are concatenated, they are realized as a short $[\mathrm{t}]$ which does not undergo spirantization (19b). In other words, phonological length (which can be deduced from morphological concatenation) is not realized as phonetic length. Instead, it is manifested by strength (i.e., it prevents lenition).

\begin{tabular}{|c|c|c|c|}
\hline Base & a. 1sG: -(a)t- $\emptyset$-aa & b. 2SG: -(a)t-t-aa & Gloss \\
\hline daqn & \begin{tabular}{|l|l} 
daqnaðaa] \\
\end{tabular} & [daqnataa] & 'feel pain' \\
\hline kabb & [kabbaðaa] & [kabbataa] & 'sip' \\
\hline tjoogso & [t]foggsaðaa] & [t fogsataa] & 'stop oneself' \\
\hline
\end{tabular}

A similar phenomenon can be observed in Tagba, a Niger-Congo language spoken in Tagbara (Burkina Faso) discussed in Traoré \& Luo (2014) and Traoré (2016). In this language, intervocalic plosives are lenited (20a). However, it is still possible to observe intervocalic plosives iff these result from a morphologically conditioned concatenation of two consonants. As in Somali, the result of this concatenation is not realized as a phonetic geminate. Instead, it is manifested by a short plosive that does not undergo lenition (20b).

\begin{tabular}{|c|c|c|c|}
\hline \multirow{5}{*}{ a. } & \multirow{2}{*}{$\begin{array}{l}\text { Phonological form } \\
\mid / c_{-}-\mathrm{t}_{\mathrm{I}} /\end{array}$} & Phonetic form & Gloss \\
\hline & & [corr] & 'gather' \\
\hline & $/ \mathrm{f} \varepsilon \mathbf{d} /$ & [fદlə] & 'dilute' \\
\hline & /cak-J/ & [ca?a] & 'look for' \\
\hline & /le-go/ & [lвyə] & 'get old' \\
\hline & $/ \mathrm{m} s \mathbf{t}+\mathbf{d} \mathrm{s} /$ & [mədə] & 'close' \\
\hline & $/ f_{\varepsilon} \mathbf{d}+\mathbf{d} \mathrm{I} /$ & {$\left[f_{\varepsilon} d_{I}\right]$} & 'trap, trapping' \\
\hline
\end{tabular}


In both of the above cases, the unexpected strength of some intervocalic consonants is related to the fact that they result from a morphological concatenation. In other words, strength can result from a phonological length which is not manifested as such phonetically.

\subsection{Proposal}

Provided that phonological length is not necessarily realized as phonetic length, it is possible to systematically represent strength with phonological branching. In this section, we illustrate this argueing that the Line Crossing Constraint can predict the distribution of length/strength.

\subsubsection{Post-coda onsets}

The Line Crossing Constraint states that association lines cannot cross. In this respect, this constraint conditions the distribution of spreading. As we saw in the previous section, spreading is not necessarily interpreted as phonetic length or assimilation. It can be an abstract mechanism motivated by structural aspects (i.e., morphological structure, syllabic structure, prosodic structure, etc.). Focusing on the observation that both long segments and virtually long segments resist lenition, we hypothesize that resistance to lenition is systematically conditioned by branching configurations. In order to derive these branching configurations, we assume that consonants always spread to a neighboring C-position if they do not violate the Empty Category Principle or the Line Crossing Constraint. It is illustrated in the representation of post-coda onsets in (21), where solid lines represent lexical associations and dotted lines represent derived associations. The post-coda onset in (21a) cannot branch to the C-position to its right because this would violate the Line Crossing Constraint. However, it can branch to the C-position to its left (21b). In line with Charette (1989), Lowenstamm (1991), Honeybone (2005) and Bucci (2013), we suggest that this post-coda onset is strong because it is a branching segment. ${ }^{10}$

${ }^{10}$ Note that this branching configuration does not belong to the underlying form. It contrasts with lexical (i.e., unpredictable) branching segments. Thus, we expect different combinatory constraints for post-coda onsets and lexical geminates. For instance, Hammond and Dupoux (1996) argue that English Expletive Infixation is impossible before an orthographic geminate (*ra-fuckin'-ccoon), but it is possible before a simple post-coda onset (fan-fuckin'-tastic). In the first case, infixation is blocked by the Line Crossing Constraint because the branching configuration is already present in the underlying form. In the second case, the infixation is possible because it applies before the spreading of the post-coda onset illustrated in (21b). 
(21) a.

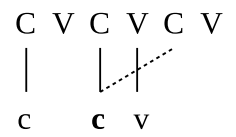

b.

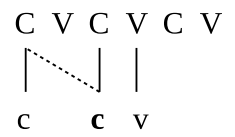

\subsubsection{Intervocalic onsets}

Now, we move on to the representation of intervocalic onsets. Unlike the previous case, intervocalic onsets cannot branch without violating the Line Crossing Constraint (22a, b). Thus, they remain short (22c). If we assume that strength is due to length, then intervocalic onsets cannot be strong.

(22) a.

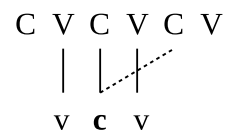

b.

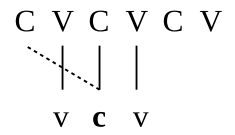

c.

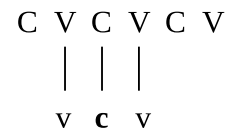

The situation becomes more complex when we need to address a distinction between two types of weak positions or two types of strong positions.

\subsubsection{Codas}

Like intervocalic onsets, codas cannot branch without crossing the line of the preceding vowel (23a) or the line of the following consonant (23b). ${ }^{11}$ Thus, we expect them to be short and weak as well (23c).

(23) a.

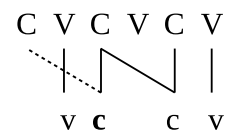

b.

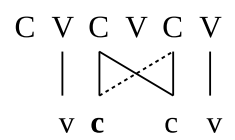

c.

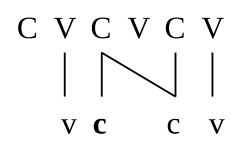

The representation of intervocalic onsets in (22c) and codas in (23c) as short and weak consonants fits with the High German case in (1). But other languages, such as French in (2), show a clear distinction between

${ }^{11}$ One could object that the coda and the following onset could be long and short respectively. For the sake of simplicity, this paper is limited to general regressive spreadings (see Javkin 1977, 143). A more detailed discussion of this aspect of the proposal is addressed in Enguehard \& Luo (2019). Our claim is that the direction of spreading is motivated by the underlying complexity of consonants. More specifically, we argue that the progressive spreading is expected in the case of branching onsets. 
the realization of intervocalic onsets and the realization of codas. We can notice that this distinction is related to the fact that intervocalic onsets have their own position (22c), while codas share their position with the following consonant $(23 \mathrm{c})$. In other terms, unlike intervocalic onsets, codas belong to a contour.

It is worth mentioning that contours (24b) are the mirror image of branching (24a). Accordingly, we suggest that contours have a mirror effect on the realization of consonants: i. branching makes stronger; but ii. contours diminish strength. ${ }^{12}$

(24) a.

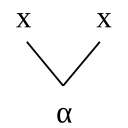

b.

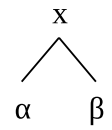

Four logical configurations can be derived:

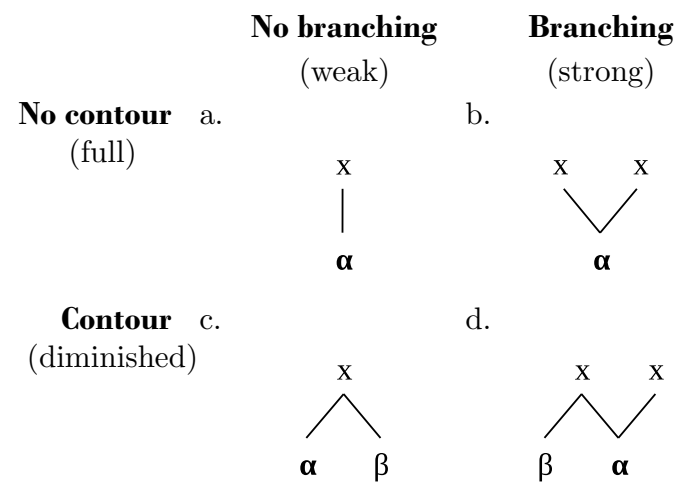

Since there is no branching and no contour, the position of $\alpha$ in $(25 \mathrm{a})$ is a full weak position. With branching and no contour, the position of $\alpha$ in (25b) is a full strong position. With contour and no branching, the position of $\alpha$ in (25c) is a diminished weak position (i.e., weaker than weak). With

${ }^{12}$ Affricates, which are generally represented with a contour, are expected to be weak segments. This is often the case in lenition paths where affricates are an intermediate step between plosives and fricatives (Harris 1994; Honeybone 2005). However, some authors consider that affricates can also result from fortition. This is the case with Ségéral \& Scheer's (2008) analysis of German data in (1). Following Enguehard (2019), we assume that such affricates are not contours, but bipositional clusters comparable to branching onsets. 
branching and contour, the position of $\alpha$ in (25d) is a diminished strong position (i.e., weaker than strong).

Of course, this does not mean that all languages should have four relevant contexts for fortition and lenition. As in Coda Mirror Theory, these configurations can be exploited or not. However, a segment cannot be lenited if it is not in a weaker configuration than another non-lenited segment. In other words, in a given language, lenition in a geminate (25b) implies lenition in post-coda onset position (25d), which implies lenition in intervocalic onset position (25a), which finally implies lenition in coda position $(25 \mathrm{c})$.

\subsubsection{Geminates}

The distinction between intervocalic onsets (25a) and codas (25c) which we proposed makes an interesting prediction concerning the specific inalterability of geminates. Compare the representation of post-coda onsets in (26a) and geminates in (26b). It can be seen that both involve length. Yet, unlike the geminate, the post-coda onset also belongs to a contour because it shares one of its positions with the preceding coda. Provided that contours diminish strength (see section 4.2.3), we expect geminates to be in a stronger position than post-coda onsets. This is indeed the case in the three languages discussed in section 3.2.

(26) a.

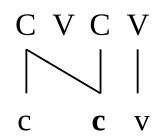

b.

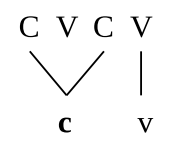

In the following subsections, we show that this model makes valid predictions concerning the specific strength of peripheral positions: initial onsets and final codas.

\subsubsection{Initial onsets}

As mentioned above, Lowenstamm (1999) proposes to represent the leftedge of words with an initial empty CV. Thus, as post-coda onsets, initial onsets can spread to a C-position on their left (27). Nevertheless, since this position is an empty slot at the left-edge of the word, initial onsets do not 
belong to any contour. Thus, we expect them to be in a stronger position than post-coda onsets. ${ }^{13}$

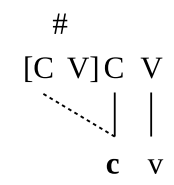

This prediction is validated by the Koalib data in (17). Compare (17a.i) and (17a.ii): initial onsets do not undergo the lenition observed in postcoda position (e.g., /tóoywór/ : [tóonwór] 'elephant' vs. /tòptànnà/ : [tòvðànnà] 'perfection'). English is another (less exotic) language showing a distinction between the strength of initial onsets and the strength of post-coda onsets. English exibits a well-known aspiration of initial and/or pretonic plosive onsets (e.g., [ $\mathbf{p}^{\mathbf{h}}$ ' $^{\prime} \mathbf{t}^{\mathbf{h}}$ eitər] 'potato') (see Iverson \& Salmons 1995). However, non-pretonic post-coda onsets are not aspirated (e.g., ['hełpın] 'helping'). Considering that both initial and pretonic onsets are preceded by an empty slot representing the left edge and stress respectively (concerning the representation of stress, see Larsen 1994; Ségéral \& Scheer 2001a; Scheer 2004; Enguehard 2016, among others), this difference is captured by the contrast between the configuration in (25b) and the configuration in (25d).

It is also important to mention that, in some languages, initial onsets behave like intervocalic onsets (e.g., Greek, see Seigneur-Froli 2002 and Ségéral \& Scheer 2008, 149). In Coda Mirror Theory, such cases are represented by a parametric absence of the initial CV proposed by Lowenstamm (1999) for languages with falling or flat sonority in initial branching onsets. In absence of preceding empty nucleus, initial onsets are automatically governed (i.e., weak). We adopt this analysis: in absence of initial $\mathrm{CV}$, the initial onset cannot branch (28). Thus, it is not strong.

${ }^{13}$ The representation of the initial consonant in (27) is the same as the representation of geminates. However, it does not mean that the contrast between initial singletons and initial geminates is neutralized. Indeed, languages that show initial geminates cannot have an initial CV because this would violate the Empty Category Principle (see Lowenstamm 1999). In this case, initial singletons do not spread to the left (see 28) and the distinction between their representation and the representation of geminates is maintained. 
(28)

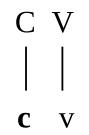

In the following subsection, we turn on to the case of final codas and the representation of their variable strength.

\subsubsection{Final codas}

As with initial onsets, our proposal predicts that final codas do not behave like internal codas. Unlike internal codas, final codas are not followed by another consonant that would branch to their position (29). Since they do not belong to any contour, they are not weaker than intervocalic onsets. This representation captures the case of languages where final codas have the same realization as intervocalic onsets but not internal codas (e.g., Polish [kon] 'horse.NOM.SG', [kon-a] 'horse-GEn.SG', [koj-ski] 'of the horse', see Scheer 2004, §582). ${ }^{14}$

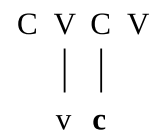

However, there are also languages where final codas do behave like internal codas. This is the case of French discussed in Ségéral \& Scheer (2008, 138): Latin obstruents dropped in both internal and final coda positions (e.g., rupta > [вut] 'road', lup(u) > [lu] 'wolf'), but not in intervocalic position (ripa $>$ [siv] 'shore'). Dropping is a specific change that can be represented in two ways: i. the loss of melodic material (30a); or ii. the loss of a skeletal position (30b). Our hypothesis is that apocope is not due to the loss of melodic material, but to the loss of a skeletal position occurring in final position (see Enguehard 2018a concerning the specificity of peripheral positions regarding the loss of skeletal slots). ${ }^{15}$

${ }^{14}$ See also the case of Arbore cited in Harris (1990, 281-282).

15 This hypothesis is supported within French by liaison and feminine inflection, which both result from loss of skeletal positions. Synchronically, they are analyzed as the presence/absence of an available skeletal position at the right-edge of the word (see Encrevé 1983; 1988; Lowenstamm 2012; Fathi \& Lowenstamm 2016). Additionally, apocope also concerns vowels (see Schane 1967 for a parallel between vowel and consonant apocope in French). 
(30) a.

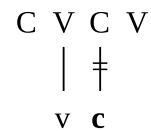

b.

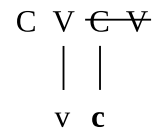

Other cases of lenition can be observed in word-final position (e.g., vocalization, debuccalization, devoicing). See the example of Brazilian Portuguese (Ségéral \& Scheer 2008, 148): original laterals where vocalized both in internal and final coda positions (e.g., sa[t] eiro 'salt cellar', sa[w] gar 'to salt', $s a[\mathbf{w}]$ 'salt' compared to European Portuguese sa[t] eiro 'salt cellar', $s a[\mathbf{f}]$ gar, $s a[\mathbf{t}])$. This phenomenon is more complex than the mere loss of a segment and deserves to be addressed more closely in further studies. For the time being, we assume that the "horizontal" organization of features is equivalent to their "vertical" organization. ${ }^{16}$ Consider the representation of a hypothetical final complex consonant $/ \alpha /$ in (31a). If the horizontal and the vertical organizations of features are equivalent, then this consonant can be indistinctly represented with two layered or two adjacent features symbolized by $\mathrm{F}_{\alpha}$. These features can be distinct or identical units depending on the chosen framework (e.g., Schane 1984; Carvalho 1993; 1994). In case of final lenition (31b), one of the features is dropped because it is situated on a separate position. Such a representation of final lenition is supported by the parallel, in the formation of the French feminine adjectives, between $\mathrm{C} / \emptyset$ alternations (e.g., [epu] 'husband' vs. [epuz] 'wife') and $f / v$ alternations (e.g., [vœf] 'widower' vs. [vœv] 'widow').

(31) Underlying consonant $/ \alpha /$

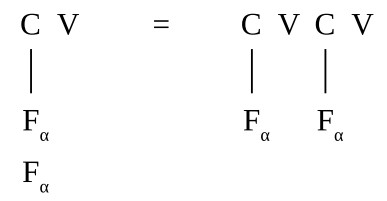

b. Final lenition of $/ \alpha /$

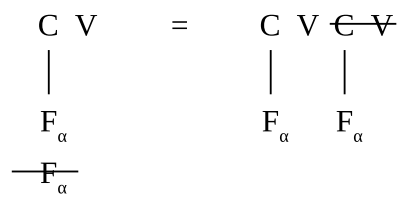

The reader should keep in mind that this mechanism is expected only in peripheral positions, where skeletal slots can drop (see Enguehard 2018a). As a consequence, this hypothesis suggests that the parametric lenition of

${ }^{16}$ See Carvalho (1994, 23), Enguehard (2016, 273-274) and Enguehard (2018b) for a similar claim concerning vowels, as well as Lowenstamm (1996) concerning the representation of secondary articulation in Chaha. Note that virtual gemination is also an avatar of this idea: quantity (i.e., horizontal) can be realized as quality (i.e., vertical). 
final codas is independent from the lenition of internal codas. This is precisely what we observe in languages with final devoicing. ${ }^{17}$ In the example of Russian in (32), for instance, voiced and voiceless obstruents contrast in intervocalic and internal coda positions $(32 \mathrm{a}, \mathrm{b})$, but they are neutralized in word-final coda position (32c). We analyze this contrast between internal and final codas as resulting from the loss of the final CV represented in (31). Assuming that the voicing feature is linked to the second position of the coda, final devoicing is triggered by the loss of the final slot.

\begin{tabular}{|c|c|c|c|}
\hline & a. Intervocalic & b. Internal Coda & c. Final Coda \\
\hline i. $/ \mathbf{k} /$ & ['okən] & [ak'nə] & [mak] (cf. ['makə] GEN.SG) \\
\hline ii. $/ \mathbf{g} /$ & $\begin{array}{l}\text { 'window.GEN.PL' } \\
\text { [a'gon'] } \\
\text { 'fire.NOM.SG' }\end{array}$ & $\begin{array}{l}\text { 'window.NOM.SG' } \\
\left.\text { [ag'n }{ }^{\mathrm{j} a}\right] \\
\text { 'fire.GEN.SG' }\end{array}$ & $\begin{array}{l}\text { 'poppy.NOM.SG' } \\
\text { [mak] (cf. ['magə] GEN.SG) } \\
\text { 'magician.NOM.SG' }\end{array}$ \\
\hline
\end{tabular}

In sections 4.2.5 and 4.2.6, we observed that the strength of initial onsets and final codas potentially differ from the strength of their respective internal counterparts. This parallel situation is captured by a unique parameter: the strength of peripheral consonants is conditioned by the presence or absence of a skeletal slot. Interestingly, this representation predicts that initial and final consonants can have the same degree of strength if both are associated to an extra peripheral slot. This is exactly what we showed for Koalib in (17). Thus, the fact that peripheral consonants resist lenition in Koalib is not a problem for our model, but rather one of its predictions.

That being said, it is important to mention that both internal and peripheral lenitions/fortitions involve the same generalization, i.e., the more space a segment has, the stronger it is. Provided that strength correlates with segmental complexity in Harris (1990), a proportional relation between length and contrastivity can be formulated in (33). ${ }^{18}$

(33) a. The more space, the more contrastive features.

b. The less space, the less contrastive features.

The only difference between internal and peripheral segments is as follows: for internal segments, the amount of space is only conditioned by the segmental environment, whereas for peripheral segments the amount of space is also conditioned by the presence/absence of an extra space at the word-edge.

${ }^{17}$ Concerning the status of final devoicing as a lenition phenomenon, see Harris (2009).

${ }^{18}$ For an illustration of the proportional relation between space and segmental complexity, see the examples of Egyptian Arabic (Fathi 2013, 45-95) or Russian (Enguehard 2018b). 


\section{Conclusion}

In this paper, we have argued that it is possible to propose a consistent theory of strength without relying on lateral relations. For this, we pointed out that Coda Mirror Theory does not capture the specificity of long segments in three reported languages: Tamazight, Old Norse and Koalib. Provided that length is a necessary notion in an account of positional strength, we proposed to remove lateral relations from this account. First, we assumed a clear distinction between phonological branching and phonetic length. Then, we suggested that strength always results from a phonological branching. Finally, we outlined a minimalist version of our proposal concerning the strength of consonants.

One issue we did not address in this paper is vocalic length. This topic will be discussed in another paper (in preparation). However, it is worth mentioning that our analysis bridges the gap between the strength of consonants and the strength of vowels. Indeed, assuming that strength is length, vowel length should not be treated differently from consonant length.

\section{Acknowledgments}

We would like to thank Quentin Dabouis, Noam Faust and Qianwen Zhao for their comments and suggestions on the content and form of this article.

\section{References}

Backley, Phillip. 2011. An introduction to Element Theory. Edinburgh: Edinburgh University Press.

Banksira, Degif P. 2000. Sound mutation: The morphophonology of Chaha. Amsterdam \& Philadelphia: John Benjamins.

Barillot, Xavier. 2002. Morphophonologie gabaritique et information consonantique latente en Somali et dans les langues Est-couchitiques. Doctoral dissertation. Université de Paris 7.

Barillot, Xavier and Philippe Ségéral. 2005. On phonological processes in the "3rd conjugation" of Somali. Folia orientalia 41. 115-131.

Bendjaballah, Sabrina. 1999. Trois figures de la structure interne des gabarits: activité morphologique du niveau squelettal des représentations phonologiques en berbère, somali et bedja. Thèse de doctorat. Université de Paris 7 .

Bendjaballah, Sabrina. 2012. La grammaire des gabarits: sur la segmentation et la linéarisation des marqueurs non concaténatifs. HDR dissertation. Université de Paris 7.

Bucci, Jonathan. 2013. Voyelles longues virtuelles et réduction vocalique en coratin. Canadian Journal of Linguistics 58. 397-414. 
Carvalho, Joaquim Brandão de. 1993. De quoi sont faites les voyelles? Phonologie tridimensionnelle des particules et harmonie vocalique. In B. Laks and M. Plénat (eds.) De natura sonorum. Paris: Presses universitaires de Vincenne. 65-100.

Carvalho, Joaquim Brandão de. 1994. What are vowels made of? The "No-rule" approach and particle phonology. Studia Linguistica 48. 1-27.

Charette, Monik. 1989. The Minimality Condition in phonology. Journal of Linguistics 25. 159-187.

Charette, Monik. 1990. Licence to govern. Phonology 7. 233-253.

Charette, Monik. 1991. Conditions on phonological government. Cambridge: Cambridge University Press.

Cyran, Eugeniusz. 1997. Resonence elements in phonology. A study in Munster Irish (PASE Studies and Monographs 3). Lublin: Wydawnictwo Folium.

Cyran, Eugeniusz. 2010. Complexity scales and licensing in phonology. Berlin \& New York: Mouton de Gruyter.

Durand, Jacques and Bernard Laks (eds.). 1996. Current trends in phonology. Models and methods. Salford: European Studies Research Institute, University of Salford Publications.

Encrevé, Pierre. 1983. La liaison sans enchaînement. Actes de la recherche en sciences sociales 46. 39-66.

Encrevé, Pierre. 1988. La liaison avec et sans enchaînement. Phonologie tridimensionnelle et usage du français. Paris: Éditions du seuil.

Enguehard, Guillaume. 2016. Vers une représentation exclusivement squelettale de l'accent : Argumentation à partir de données du same du sud, du live, du norrois et du russe. Doctoral dissertation. Université de Paris 7.

Enguehard, Guillaume. 2018a. Strict CV without government. Acta Linguistica Academica 65. $29-45$.

Enguehard, Guillaume. 2018b. A thought on the form and the substance of Russian vowel reduction. In D. Lenertová, R. Meyer, R. Šimík and L. Szucsich (eds.) Advances in formal Slavic linguistics. Berlin: Language Science Press. 109-125.

Enguehard, Guillaume. 2019. Branching onsets and the OCP. In Szpyra-Kozłowska \& Radomski (2019, 19-32).

Enguehard, Guillaume and Xiaoliang Luo. 2019. Length and reduplication of branching onsets. In Szpyra-Kozłowska \& Radomski (2019, 33-46).

Fathi, Radwa. 2013. La longueur vocalique en arabe égyptien: une nouvelle conception. Doctoral dissertation. Université de Paris 7.

Fathi, Radwa and Jean Lowenstamm. 2016. The gender assignment pattern of French nouns: Selection and allomorphy. Morphology 26. 477-509.

Faust, Noman. 2018. Bi-morphemic virtual length in Yiddish. Studia Linguistica 72. 608624.

Gordon, Eric and Arnold Taylor. 1957. An introduction to Old Norse. Oxford: Oxford University Press.

Guerssel, Mohammed. 1977. Constraints on phonological rules. Linguistic Analysis 3. 267-305.

Guerssel, Mohammed. 1978. A condition on assimilation rules. Linguistic Analysis 4. $225-254$. 
Gussmann, Edmund and Jonathan Kaye. 1993. Polish notes from a Dubrovnik café. SOAS Working Papers in Linguistics and Phonetics 3. 427-462.

Hammond, Michael and Emmanuel Dupoux. 1996. Psychophonology. In Durand \& Laks (1996, 281-304).

Harris, John. 1990. Segmental complexity and phonological government. Phonology 7. $255-300$.

Harris, John. 1994. English sound structure. Oxford \& Cambridge, MA: Blackwell.

Harris, John. 2009. Why final obstruent devoicing is weakening. In K. Nasukawa and P. Backley (eds.) Strength relations in phonology. Berlin \& New York: Mouton de Gruyter. 9-46.

Hayes, Bruce. 1986. Inalterability in CV Phonology. Language 62. 321-351.

Honeybone, Patrick. 2001. Lenition inhibition in Liverpool English. English Language and Linguistics 5. 213-249.

Honeybone, Patrick. 2005. Sharing makes us stronger: Process inhibition and segmental structure. In P. Carr, J. Durand and C. J. Ewen (eds.) Headhood, elements, specification and contrastivity: Phonological papers in honour of John Anderson. Amsterdam \& Philadelphia: John Benjamins. 167-192.

Iverson, Gregory K. and Joseph C. Salmons. 1995. Aspiration and laryngeal representation in Germanic. Phonology 12. 369-396.

Javkin, Hector. 1977. Phonetic universals and phonological change. Doctoral dissertation. UC Berkeley.

Kambuziya, Aliyeh. 2003. Lenition in phonological patterns of Persian. Journal of Humanities 10. 13-18.

Kaye, Jonathan D. 1990. 'Coda' licensing. Phonology 7. 301-330.

Kaye, Jonathan D. 1992. Do you believe in magic? The story of $\mathrm{s}+\mathrm{C}$ sequences. SOAS Working Papers in Linguistics \& Phonetics 2. 293-313.

Kaye, Jonathan D., Jean Lowenstamm and Jean-Roger Vergnaud. 1990. Constituent structure and government in phonology. Phonology 7. 193-231.

Kenstowicz, Michael. 1970. On the notation of vowel length in Lithuanian. Papers in Linguistics 3. 73-113.

Kossmann, Marteen. 2000. Esquisse grammaticale du rifain oriental. Paris: Peeters.

Larsen, Uffe. 1994. Some aspects of vowel length and stød in modern Danish. MA thesis. Université de Paris 7.

Lavoie, Lisa. 2001. Consonant strength: Phonological patterns and phonetic manifestations. London \& New York: Routledge.

Leben, William. 1980. A metrical analysis of length. Linguistic Inquiry 11. 497-509.

Leben, William R. 1973. Suprasegmental phonology. Doctoral dissertation. MIT.

Lowenstamm, Jean. 1991. Vocalic length and syllable structure in Semitic. In A. S. Kaye (ed.) Semitic studies in honor of Wolf Leslau on the occasion of his 85th birthday. Wiesbaden: Harrassowitz. 949-965.

Lowenstamm, Jean. 1996. CV as the only syllable type. In Durand \& Laks (1996, 419-441).

Lowenstamm, Jean. 1999. The beginning of the word. In J. Rennison and K. Kühnhammer (eds.) Phonologica 1996. Syllables!? The Hague: Holland Academic Graphics. $153-166$. 
Lowenstamm, Jean. 2012. Feminine and gender, or why the feminine profile of French nouns has nothing to do with gender. In E. Cyran, H. Kardela and B. Szymanek (eds.) Sound, structure and sense. Studies in memory of Edmund Gussmann. Lublin: Wydawnictwo KUL. 371-406.

Martinet, André. 1955. Économie des changements phonétiques: Traité de phonologie diachronique. Berne: A. Francke.

McCarthy, John J. 1986. OCP effects: Gemination and antigemination. Linguistic Inquiry 51. 207-263.

Pöchtrager, Markus Alexander. 2006. The structure of length. Doctoral dissertation. Universität Wien.

Quint, Nicolas. 2006. Phonologie de la langue koalibe. Paris: L'Harmattan.

Saib, Jilali. 1974. Gemination and spirantization in Berber: Diachrony and synchrony. Studies in African Linguistics 5. 1-25.

Schane, Sandford. 1967. L'élision et la liaison en français. Languages 2. 37-59.

Schane, Sanford A. 1984. The fundamentals of Particle Phonology. Phonology Yearbook 1. $129-155$.

Scheer, Tobias. 1996. Une théorie de l'interaction directe entre consonnes. Contribution au modèle syllabique $\mathrm{CVCV}$, alternances e- $\emptyset$ dans les préfixes tchèques, structure interne des consonnes et la théorie X-barre en phonologie. Doctoral dissertation. Université de Paris 7.

Scheer, Tobias. 2004. A lateral theory of phonology. Vol 1: What is CVCV, and why should it be? Berlin \& New York: Mouton de Gruyter.

Scheer, Tobias and Markéta Ziková. 2010. The Coda Mirror v2. Acta Linguistica Hungarica 57. $411-31$.

Ségéral, Philippe. 1995. Une théorie généralisée de l'apophonie. Doctoral dissertation. Université de Paris 7.

Ségéral, Philippe and Tobias Scheer. 1999. The Coda Mirror. Ms. Université de Paris 7 and Université de Nice.

Ségéral, Philippe and Tobias Scheer. 2001a. Abstractness in phonology: The case of virtual geminates. In K. Dziubalska-Kołaczyk (ed.) Constraints and preferences. Berlin \& New York: Mouton de Gruyter. 130-172.

Ségéral, Philippe and Tobias Scheer. 2001b. La Coda-Miroir. Bulletin de la Société de Linguistique de Paris 96. 107-152.

Ségéral, Philippe and Tobias Scheer. 2008. Positional factors in lenition and fortition. In J. B. de Carvalho, T. Scheer and P. Ségéral (eds.) Lenition and fortition. Berlin \& New York: Mouton de Gruyter. 131-172.

Seigneur-Froli, Delphine. 2002. Greek ptero: Neither extrasyllabicity nor magic. Paper presented at Phonologica 2002.

Steriade, Donca. 1982. Greek prosodies and the nature of syllabification. Doctoral dissertation. MIT.

Steriade, Donca and Barry Schein. 1984. Geminates and structure-dependent rules. In M. Cobler, S. MacKaye and M. T. Wescoat (eds.) Proceedings of the West Coast Coneference on Formal Linguistics. Volume three. Stanford, CA: The Stanford Linguistics Association, Department of Linguistics, Stanford University. 263-29. 
Szpyra-Kozłowska, Jolanta and Marek Radomski (eds.). 2019. Phonetics and phonology in action. Berlin: Peter Lang.

Thurneysen, Rudolf. 1946. A grammar of Old Irish. Dublin: Dublin Institute for Advanced Studies.

Traoré, Mori. 2016. Etude ethnolinguistique du sıcanє (chant de hochets des femmes senufo du tagbara). Doctoral dissertation. Université d'Orléans.

Traoré, Mori and Xiaoliang Luo. 2014. Séquence de consonnes aux frontières morphologiques en tagba. Paper presented at the 12th Meeting of the French Phonology Network, Lille.

Ulfsbjorninn, Shanti and Mohamed Lahrouchi. 2016. The typology of the distribution of Edge: The propensity for bipositionality. Papers in Historical Phonology 1. 109-129.

Zoëga, Geir. 1910. A concise dictionary of Old Icelandic. Oxford: Clarendon Press. 